\title{
Physicians With AIDS: A Proposal For Efficient Disclosure
}

\author{
Jennifer Hertz†
}

Dr. Smith dies of an AIDS-related condition. ${ }^{1}$ Dr. Jones tests positive for HIV antibodies. ${ }^{2}$ The hospitals that employed Drs. Smith and Jones consult legal counsel to determine whether to disclose the physicians' HIV status to their former patients. The hospital officials wish to prevent further harm from the physicians' HIV exposure. ${ }^{3}$ The hospitals notify the physicians' decedents of their intent to release the doctors' names and HIV status to former

† A.B. 1985, Wellesley College; J.D. Candidate 1992, The University of Chicago.

1 Acquired Immunodeficiency Syndrome ("AIDS") is a fatal disease that develops after infection by the human immunodeficiency virus ("HIV"). See Centers for Disease Control ("CDC"), AIDS and Human Immunodeficiency Virus Infection in the United States: 1988 Update, 38 Morbidity and Mortality Wkly Rpt Supp 4, 1 (May 12, 1989). An individual may be infected with HIV but not have AIDS. A diagnosis of AIDS is made when a patient tests positive for HIV antibodies and has an accompanying opportunistic infection or a cancer that characteristically attacks individuals with immune systems suppressed by HIV. A person with HIV infection who does not manifest any of the infections or cancers typically associated with AIDS, nonetheless has AIDS when her T-cell count (immune system cells destroyed by the virus) decreases to 200 or fewer cells per cubic millimeter of blood. See Mireya Navarro, AIDS Definition is Widened to Include Blood Cell Count, NY Times, D21-D22 (Aug 8, 1991). See also Michael J. Clement and Merle A. Sande, Approach to the Acquired Immune Deficiency Syndrome, in William Kelley, ed, Textbook of Internal Medicine 1789-96 (J.B. Lippincott Co., 1989).

2 Though procedures exist to test for HIV directly, the standard HIV test reveals the presence of HIV antibodies, thereby indirectly indicating the presence of HIV. See Timothy Bishop, Introduction to HIV Testing (unpublished manuscript, on file with U Chi L Rev) (details HIV tests and their reliability). See also CDC, Update: Serologic Testing for HIV-1 Antibody-United States, 1988 and 1989, $264 \mathrm{~J}$ Am Medical Ass'n 171 (1990). In 95\% of HIV-infected persons, positive antibody tests are found within six months of the date of transmission. However, the length of the maximum window period between HIV infection and HIV antibody presence is as yet undetermined. Robert Horsburgh, et al, Duration of Human Immunodeficiency Virus Infection Before Detection of Antibody, 2 The Lancet 637 (1989).

The term "HIV-positive" refers to individuals whose HIV antibody tests reveal the presence of HIV. "HIV-negative" refers to individuals whose HIV antibody tests do not reveal the presence of HIV. As stated earlier, HIV-negative patients may still have HIV.

${ }^{3}$ The phrase "from the physicians' HIV exposure" is intentionally used instead of "potential exposure to HIV". The negligence equation used throughout this Comment, $B<P^{*} L$, looks at the total cost of accidents $(L)$ in the absence of cautionary expenditure and separately factors in the probability $(P)$ that the accident will occur. See text accompanying notes 57-65. 
patients. Dr. Jones's and Dr. Smith's decedents sue to enjoin the hospitals' intended releases.

In another scenario, an individual who tests positive for HIV antibodies sues a hospital for negligence. In her suit, she claims that she contracted the virus from a former patient, who had been infected by the patient's physician, and seeks to discover the identity of the patient's physician.

These two scenarios are different sides of the same coin. In the first, physicians or their families sue to prevent disclosure of their identities, while a hospital seeks disclosure to avoid ultimate liability. ${ }^{4}$ In the second scenario, a third party sues the hospital to obtain an HIV-infected employee's name, while the hospital seeks to protect its employee's privacy and avoid disclosure. To resolve these disclosure issues, courts must establish a level of due care that determines when hospitals must disclose the identity of HIVinfected health care workers.

A recent case of alleged HIV transmission from a health care professional $^{5}$ to his patients has renewed interest in disclosure of the HIV status of physicians. As a result of this single case,${ }^{\beta}$ health departments, hospitals and other medical institutions have instituted "lookback" policies, whereby they notify the former patients of physicians who die of HIV-related conditions. ${ }^{8}$ A hospital's decision to perform a lookback may reduce the number of persons ex-

\footnotetext{
- A hospital may also wish to avoid the negative publicity that will likely result if the information is eventually uncovered without the hospital having voluntarily disclosed it.

- Although the preceding hypotheticals concern physician disclosure, this Comment is relevant to health care workers generally. The CDC define health care workers as "persons, including students and trainees, whose activities involve contact with patients or with blood or other body fluids from patients in a health-care setting." Centers for Disease Control, Recommendations for Prevention of HIV Transmission in Health-Care Settings, 36 Morbidity and Mortality Wkly Rpt Supp 2, 3 (Aug 21, 1987).

- See CDC, Possible Transmission of Human Immunodeficiency Virus to a Patient During an Invasive Dental Procedure, 39 Morbidity and Mortality Wkly Rpt, No 29, 489 (Jul 27, 1990). The CDC later revealed that five of the dentist's patients tested HIV-positive and that the dentist likely had transmitted the virus to three of them. See CDC, Update: Transmission of HIV Infection During Invasive Dental Procedures-Florida, 40 Morbidity and Mortality Wkly Rpt, No 23, 377 (Jun 14, 1991). There are no other reported cases of suspected HIV transmission from a health care worker to a patient.

7 The terms "lookback", "lookback notification", and "notification" are used interchangeably throughout this Comment.

a For some examples of recent lookbacks performed by medical institutions, see Jean Latz Griffin, Dental Student Has HIV, Patients Told, Chi Trib C1 (Jul 24, 1991) (dental school notified patients that they had been treated by an HIV-positive dental student); Doctor Died of AIDS, Hospital Tells Parents, NY Times A16 (Apr 11, 1991) (hospital notified the parents of 59 patients that a medical resident had died of AIDS); and AIDS Doctor Revealed, Newsday 16 (Jun 2, 1991) (hospital notified more than 5,000 patients of an exstaff anesthesiologist two weeks after he died from AIDS-related conditions).
} 
posed to HIV as a result of medical workplace exposures and may also reduce the cost of the lawsuits that follow.

An economic analysis suggests that courts should require hospitals to disclose their physician-employee's HIV status only if the benefit in reducing expected accident costs is greater than the costs of notification. ${ }^{9}$ In other words, hospitals should be allowed or required to perform lookbacks when the cost of accidents prevented by lookback, multiplied by the probability of an accident occurring, exceeds the cost incurred as a result of lookbacks. This Comment uses the basic Learned Hand formula $B<P^{*} L^{10}$ to provide a legal framework for determining when hospitals ${ }^{11}$ should be allowed to carry out lookback notifications.

Section I discusses the current legal approaches to HIV status disclosure in the health-care setting. Section II introduces the proposed equation and explores the economic basis of the negligence inquiry. Section III analyzes each variable in the equation and provides some guidance for assigning relative cost estimates. Section IV interprets the equation and advises when and to what extent to release the identity of HIV-infected health care workers.

\section{BACKGROUND}

Courts, legislatures, and medical institutions have participated in lookbacks. An analysis of blood donor and lookback cases supports the cost-benefit model that this Comment proposes. The model finds additional support in legislation that addresses lookbacks and the notification practices of medical institutions.

\section{A. Caselaw}

1. The donor cases.

The issues surrounding HIV status disclosure are familiar to the courts. Many courts have resolved the disclosure issue by balancing the parties' competing interests. In particular, this issue of lookbacks has been raised during discovery proceedings in litigation involving HIV transmission through blood transfusions. ${ }^{12}$ In

- See Richard A. Posner, Economic Analysis of Law § 6.1 at 149-50 (Little, Brown, 3d ed 1986).

10 United States v Carroll Towing Co., 159 F2d 169, 173 (2d Cir 1947).

11 The term "hospital" is used for simplicity. This same formulaic evaluation should apply to public health departments, individual practitioners, small medical groups, or any other health care organization contemplating a lookback.

${ }_{12}$ Many commentators have discussed HIV-status disclosure in the context of HIV infection arising from blood transfusions. See Richard C. Bollow and Daryl J. Lapp, Protect- 
six cases, state courts have used cost-benefit analysis to decide whether to require disclosure of the identities of blood donors. ${ }^{13}$

a) Preventing discovery. Two state courts have blocked disclosure of blood donors' identities and denied discovery requests using balancing tests. ${ }^{14}$ In Rasmussen $v$ South Florida Blood Service, the plaintiff sought to discover the identities of fifty-one blood donors after receiving an HIV-tainted blood transfusion. The plaintiff sought to establish that he had contracted AIDS from the HIV-infected blood. The court held, however, that the violation of the donors' privacy and the resulting "serious disincentive to volunteer blood donation" outweighed the minimal probative value of the discovery sought. ${ }^{16}$ The Florida Supreme Court recognized the "state's important interest in the fair and efficient resolution of disputes," but believed that refusal to disclose the donors' identities would provide "protective measures to minimize the impact of discovery on competing privacy interests." 16 In sum, the court concluded that disclosure would have implicated the donors' privacy rights under the United States and Florida Constitutions. ${ }^{17}$

Confronted with strikingly analogous facts, ${ }^{18}$ a New York court also used a balancing test to deny discovery of donor identities, but on different grounds. In Krygier $v$ Airweld, Inc, the court expressly declined to address the donors' constitutional privacy argument. Rather, the court based its decision on the physician-patient privilege and society's interest in an adequate blood supply. ${ }^{19}$ The court concluded that "[e]xposing donors to public scrutiny in order to determine what they may have told [the blood bank] has only marginal utility in advancing the plaintiff's theory of liabil-

ing the Confidentiality of Blood Donors' Identities in AIDS Litigation, 37 Drake L Rev 343 (1987-1988); Karen Shoos Lipton, Blood Donor Services and Liability Issues Relating to Acquired Immune Deficiency Syndrome, 7 J Legal Med 131 (1986); Note, AIDS: Anonymity in Donation Situations-Where Public Benefit Meets Private Good, 69 B U L Rev 187 (1989); Note, Transfusion-Related AIDS Litigation: Permitting Limited Discovery from Blood Donors in Single Donor Cases, 76 Cornell L Rev 927 (1991).

${ }_{13}$ These six cases are discussed from a policy perspective in Note, 76 Cornell $\mathrm{L}$ Rev at 927 (cited in note 12).

14 Rasmussen v South Florida Blood Service, 500 S2d 533, 535 (Fla 1987); Krygier v Airweld, Inc, 137 Misc 2d 306, 520 NYS2d 475, 477 (1987).

1s Rasmussen, $500 \mathrm{~S} 2 \mathrm{~d}$ at 538 (quoting $467 \mathrm{~S} 2 \mathrm{~d} 798,804$ (1985)).

16 Id at 535 .

17 Id at 537.

${ }^{18}$ In Krygier, the blood bank was one of several defendants in a wrongful death action. Plaintiff's decedent allegedly contracted AIDS in a transfusion following an industrial accident. The decedent's wife sought discovery of the donors' identity. Krygier, 520 NYS2d at 475.

29 Id at 477. 
ity."20 Thus, both blood donor cases preventing discovery involved balancing tests.

b) Compelling discovery. Again using a balancing test, a state appellate court upheld the lower court's order compelling the hospital's disclosure of donor identities in a wrongful death action. In Tarrant County Hospital District $v$ Hughes, ${ }^{21}$ the plaintiff's daughter contracted HIV through a blood transfusion. In response to the plaintiff's request for the names and addresses of blood donors, the lower court crafted a modified order that allowed discovery of donors' names but directed the plaintiff to obtain a further court order before contacting donors. ${ }^{22}$ In reviewing this order the appellate court compared the state interest served by the order with the donors' interest in privacy..$^{23}$ The court concluded that the discovery order did not violate the donor's right to privacy and that the hospital failed to. show that the injury to society's interest caused by disclosure outweighed its benefit. ${ }^{24}$

In three other blood transfusion cases, courts have allowed limited discovery of donors while protecting their identities. The court in Boutte $v$ Blood Systems, Inc., ${ }^{25}$ balanced the parties' competing interests and held that the plaintiff could proceed with limited discovery, provided that (1) depositions included only written questions and answers, (2) the donor could refuse to provide identifying information, and (3) the blood bank's counsel could secure donor confidentiality. ${ }^{26}$ In Belle Bonfils Memorial Blood Center $v$ District Court, where a patient contracted the virus through a blood transfusion, the Colorado Supreme Court allowed controlled discovery of a single blood donor's identity, by limiting depositions to a written questionnaire. ${ }^{27}$ Finally, the court in Mason $v R e-$ gional Medical Center of Hopkins County, allowed disclosure but attempted to safeguard the donor's privacy by limiting disclosure to one attorney on each side. ${ }^{28}$

The blood transfusion cases reveal that courts have generally balanced donors' privacy interests against the plaintiffs' interest in disclosure when deciding whether to permit discovery of donors'

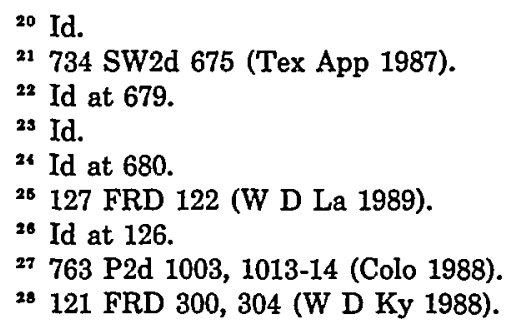


identities. In cases involving lookback, courts must strike the same delicate balance.

2. Litigated lookbacks.

In the United States, three $\operatorname{cases}^{29}$ have specifically addressed the disclosure of the identities of HIV-infected health care workers. In Estate of Behringer $v$ Medical Center at Princeton, ${ }^{30}$ plaintiff-decedent sued as a result of the defendant hospital's failure to keep plaintiff's diagnosis and test results confidential. The plaintiff worked for the defendant hospital as a physician. ${ }^{31}$ When he fell ill, Dr. Behringer checked into the defendant's medical center. ${ }^{32}$ Fearful that news of his diagnosis would destroy his professional career, however, he checked out of the hospital shortly thereafter. ${ }^{33}$ Nonetheless, patient cancellations and inquiring phonecalls led him to suspect that hospital employees had revealed the diagnosis. ${ }^{34}$ Dr. Behringer charged the hospital with negligent failure to assure his confidentiality, which, he asserted, damaged his professional reputation. ${ }^{35}$

The Superior Court of New Jersey held that the hospital negligently failed to keep Dr. Behringer's diagnosis confidential. ${ }^{36}$ The court deemed the plaintiff's status as defendant's employee particularly relevant. The court found that "[b]ecause the stakes are so high in the case of a physician being treated at his own hospital, it is imperative that the hospital take reasonable steps to insure the confidentiality" of the diagnosis. ${ }^{37}$ Moreover, the court discounted defendant's possible competing interest in disclosure. Any balancing of interests clearly fell in favor of the physician. ${ }^{38}$

Unlike the Behringer court, the Fifth Circuit in Leckelt $v$ Board of Commissioners of Hospital District No. $1^{39}$ allowed disclosure based on a balancing of interests that included the health

\footnotetext{
${ }^{28}$ A fourth lookback case was litigated in England. In that case, a British health authority sought an injunction against the defendant newspaper to prevent publication of the HIV status of two physicians with AIDS. The court found that the physicians' privacy rights outweighed society's interest in a free press. $X v Y, 2$ All E L Rep 648, 648 (1988).

30 249 NJ Super 597, 592 A2d 1251 (1991).

$31592 \mathrm{~A} 2 \mathrm{~d}$ at 1255.

32 Id.

${ }^{33}$ Id at 1256.

34 Id.

38 Id at 1268.

${ }^{36}$ Id at 1273-74.

37 Id at 1272-73.

${ }^{38} \mathrm{Id}$ at 1273.

39 909 F2d 820 (5th Cir 1990).
} 
care worker's right to privacy. Kevin Leckelt was a licensed practical nurse at Terrebone General Medical Center, a government hospital in Louisiana. ${ }^{40}$ The chairperson of the Medical Center's infection control committee alleged to the chief of staff that Leckelt was an "associate" of an AIDS patient there. To comply with the HIV and AIDS guidelines of the Centers for Disease Control and the American Hospital Association, the committee requested that Leckelt disclose to it the results of a recent HIV antibody test. ${ }^{41}$ Convinced that Leckelt would not submit the test results, the Medical Center terminated his employment for failure to comply with its policies. ${ }^{42}$ Leckelt sued, arguing that the Medical Center's disclosure requirement violated his civil rights under federal and Louisiana constitutional and statutory provisions. ${ }^{43}$

In upholding the hospital's disclosure requirement, the court weighed Leckelt's privacy interests against the Medical Center's interest in knowing Leckelt's health status. ${ }^{44}$ The court found Leckelt had a "diminished" privacy interest because he voluntarily worked for a hospital that had standing policies requiring its employees to undergo medical testing "where necessary" and because, by his own admission, Leckelt had already undergone HIV antibody testing. ${ }^{45}$ The court held that Leckelt's diminished privacy interest failed to overcome the Medical Center's fundamental interest in protecting the health of its employees and patients. The court compared the Medical Center's claim to an employer's interest in a safe, efficient workplace-an interest that the Supreme Court has deemed significant. ${ }^{46}$ Without relying on any expert testimony, the court stated that "Leckelt's duties as a licensed practical nurse provided opportunities for HIV transmission."47

Few other courts have faced the issue of disclosure of the identities of HIV-infected health care workers. In Doe v Federal Bu-

10 Id at 821.

11 Id at 822 .

12 Id at 824 .

${ }^{43}$ Id. See Federal Rehabilitation Act of 1973, 29 USC § 794 (Supp 1991); Louisiana Civil Rights for Handicapped Persons Act, La Rev Stat $\$ \S 46: 2251$ et seq (West, 1980); US Const, Amend IV; and US Const, Amend XIV.

" Leckelt, 909 F2d at 832-33. The court also considered Leckelt's charge of discrimination under the Federal Rehabilitation Act of 1973, id at 824-30, and his equal protection argument based on membership in the class of handicapped persons. Id at 831-32. Both of these arguments were rejected by the court. Id at 830,832 .

45 Id at 833.

16 Id, citing National Treasury Employees Union v Von Raab, 489 US 656, 671 (1989) (holding that a warrant is not constitutionally required before the United States Customs Service tests employees applying for specified positions for drug use).

17 Id at 833. 
reau of Prisons, ${ }^{48}$ an HIV-infected dentist who practiced at the Metropolitan Correctional Center in Chicago sought to restrain the Federal Bureau of Prisons from issuing a press release, posting notices on bulletin boards at all federal prisons, and taking other actions that would reveal his identity and HIV-positive status. A United States district court refused to issue a temporary restraining order and allowed the wide distribution of the dentist's identity.

The courts that have considered public or limited disclosure of HIV test results have provided neither a clear test nor a method for resolving hard cases. In the blood transfusion cases, courts have attempted, with conflicting results, to balance competing interests. ${ }^{49}$ In lookback cases, courts generally have neither employed a balancing test nor provided any other framework upon which to decide future cases. ${ }^{30}$ Thus, the burgeoning issue of HIV transmission in health care settings awaits a rule that offers consistent and predictable guidance in resolving disclosure conflicts. This Comment's analytical model seeks to provide such a rule. ${ }^{51}$

\section{B. Legislation}

Current legislation concerning the rights and responsibilities of patients and physicians may help determine whether lookbacks will be performed as part of a hospital's general practice. At least one state has enacted legislation that requires the state health department to consider notifying patients if their health-care provider has AIDS and has performed invasive procedures. ${ }^{52}$ Such federal and state legislation may influence judges' evaluations of the costs of disclosure, even if such costs are found not to be dispositive in the decision to conduct a lookback.

In addition to legislation specifically addressing lookbacks, Congress has passed laws that effectively insulate persons with

${ }_{48}^{4}$ No 91-C-5013 (N D Ill, Aug 9, 1991), discussed in 1991 AIDS Litigation Rep 6833 (Sep 13, 1991).

${ }^{19}$ See Rasmussen, $500 \mathrm{~S} 2 \mathrm{~d}$ at 537 (denying discovery request); Tarrant, $734 \mathrm{SW} 2 \mathrm{~d}$ at 679 (compelling discovery with a court order).

so See, for example, Behringer, 249 NJ Super 597.

${ }^{31}$ This Comment focuses on lookbacks because they may be the most contested area of HIV-status disclosure in the near future. Nevertheless, courts may apply the model offered by this Comment to resolve other disclosure cases.

82 Act Relating to AIDS, 1991 Ill Advanced Leg Service 763, 1991 Pub Act 763, 1991 Ill Sen Bill 999. Note that there is some confusion as to the impact of this legislation given that the Illinois Department of Public Health does not collect the names or professional information of people infected with HIV until they receive a diagnosis of AIDS. 
HIV disease from discrimination based on disability. The Federal Rehabilitation Act of 1973 ("FRA") 53 and the Americans with Disabilities Act of 1990 ("ADA") ${ }^{54}$ reflect Congress's determination that compensable damages arise from discrimination on the basis of disability. Further, as argued below, ${ }^{\mathrm{bs}}$ courts may use this legislation to guide their evaluations of costs associated with discrimination, an important component of the total cost of a lookback. This Comment explains the argument that lookbacks may constitute a violation of the FRA, the ADA, or both. Moreover, under the analytical model proposed, no actual violation of either the FRA or the ADA is required to find that discrimination on the basis of disability represents a cost of lookback. ${ }^{56}$

\section{The Negligence Equation}

Thus far, courts that have considered whether to disclose the identity of HIV-positive health care workers have applied neither consistent nor theoretically sound analytic methods. An acceptable method would offer principled criteria to determine when disclosure would be socially beneficial. Economic analysis of law provides one such method for determining when notification efficiently prevents future damage.

Specifically, this Comment proposes that courts adopt a negligence standard for determining whether a lookback is or was appropriate. Under such a standard, hospitals would be liable for injuries resulting from failure to conduct a lookback when the total costs of notification are less than the total costs of non-notification. Accordingly, hospitals would be liable for injury resulting from a lookback when the total costs of notification are greater than the total costs of non-notification. In sum, the standard should encourage hospitals to make efficient lookback decisions.

The negligence formula begins with the uncontroversial notion that a self-interested patient would want to know the HIV status of her physician before submitting to a medical procedure, ${ }^{57}$ and, based on principles of informed consent, that patient may have a right to know. ${ }^{58}$ An informed patient would likely act on such

\footnotetext{
${ }^{63}$ Federal Rehabilitation Act of 1973, 29 USC $\S 794$ (Supp 1991).

s4 Americans with Disabilities Act of 1990, 42 USC $\S \S 12101$ et seq (Supp 1991).

os See text accompanying notes 84-107.

so See Section III.A.2.

${ }^{67}$ See Larry Gostin, Hospitals, Health Care Professionals, and AIDS: The "Right to Know" The Health Status of Professionals and Patients, $48 \mathrm{Md} \mathrm{L} \mathrm{Rev} \mathrm{12,} 23$ (1989).

${ }^{88}$ See Lawrence Gostin, HIV-Infected Physicians and the Practice of Seriously Invasive Procedures, 19 Hastings Ctr Rpt 32 (1989) (analysis of patient's right to know).
} 
knowledge by choosing a non-HIV-infected physician beforehand. ${ }^{59}$ Therefore, lookback questions should arise only when the physician did not know she was HIV-infected or when she knew but did not disclose that information to the patient. Thus the issue is whether a lookback procedure, as performed by the physician's employer, can ameliorate, after treatment, the costs of the physician's failure to disclose before treatment.

As in the cases of nondisclosure of the risks of medical procedures, ${ }^{60}$ courts in lookback cases should focus the negligence inquiry on the hospital rather than on the physician. As an employer, the hospital should ensure that no physician-employee poses a material risk to patients. ${ }^{61}$ Further, in a practical sense, the hospital is more likely to be responsive to claims raised by former patients. By the time a lookback is considered, the HIV-infected physician may be ill, insolvent, uninterested, or dead.

A negligence standard for lookback is consistent with customary judicial practice in that courts have traditionally employed a negligence standard to determine liability in cases of nondisclosure of risks of treatment. ${ }^{62}$ One of the most popular forms of the negligence inquiry is the economic approach first formally advanced by Judge Learned Hand. In the famous case of United States $v$ Carroll Towing, ${ }^{63}$ Judge Hand proposed that courts set the standard of due care in tort cases according to a simple economic equation.

The equation Judge Hand proposed is expressed as $B<P^{*} L$. The variable $B$ denotes the cost of a precaution. $P^{*} L$ represents expected accident cost as a function of the probability of the loss occurring, were precaution not taken $(P)$, multiplied by the magnitude of that loss $(L) . P^{*} L$ is ultimately compared to the cost of $B .^{64}$ If $B$ is less than $P^{*} L$, it is negligent not to institute the precaution.

In the case of lookback, the cost of the precaution $(B)$ is determined according to the economic cost of notification, the cost to the physician, the cost to persons associated with the physician, and the cost to society at large. The expected accident cost $\left(P^{*} L\right)$ depends on the risk estimates of HIV transmission through physi-

${ }^{89}$ Gostin, $48 \mathrm{Md} \mathrm{L}$ Rev at 23 (cited in note 57).

${ }^{80}$ See, for example, Canterbury v Spence, 464 F2d 772 (DC Cir 1972).

${ }^{61}$ Gostin, $48 \mathrm{Md} \mathrm{L}$ Rev at 14 (cited in note 57).

${ }^{62}$ See Richard Prosser and W. Page Keeton, Prosser and Keeton on Torts $\S 18$ at 121, $\S 32$ at 190-91 (West, 5th ed 1984).

${ }^{63}$ See United States $v$ Carroll Towing Co., 159 F2d 169, 173 (2d Cir 1947).

64 A more detailed explanation with examples is provided in Posner, Economic Analysis of Law at 147-51 (cited in note 9). 
cian exposure $(P)$ multiplied by the magnitude of the marginal increase in losses suffered if lookback is not performed.65

Where the patient has been exposed to HIV through contact with an infected physician (that is, where the value of $L$ is greater than zero), some costs cannot be avoided with or without a lookback. Performing a lookback in this instance will not change the fact that the patient may have contracted HIV and as a result has a significantly higher chance of testing HIV-positive in the future. ${ }^{66}$ However, a lookback may reduce losses associated with the initial transmission. Specifically, lookback and notification puts atrisk patients on notice; it encourages the patient to seek testing for HIV infection. If that patient turns out to be infected, the patient may be able to seek early treatment and thus live longer than if she was not aware that she had been infected. ${ }^{67}$ In this sense, the lookback decreases the magnitude of $L$ to the patient. Additionally, a lookback could eliminate significant losses arising from transmission by the patient to third parties. ${ }^{68}$ The costs associated with performing the lookback, $B$, should be compared to the change in $P^{*} L$ given a lookback as compared to $P^{*} L$ were no lookback performed.

\section{Evaluating the Equation}

To use the Hand formula in a lookback case, courts must evaluate the many factors that affect the variables $B$ and $P^{*} L$. This section identifies judicially and legislatively recognized costs of disclosure, reviews existing information about the likelihood of HIV transmission, and discusses the possibilities of reducing harm once transmission has occurred.

G5 It may be easier to think of $L$ as the negative of the benefits that a lookback generates if performed.

so Note that for the purposes of evaluating whether a lookback should be allowed or required, $P^{*} L$ should include only secondary costs of exposure. That is, $P^{*} L$ equals the cost of accidents without notification $\left(C_{w n}\right)$, less the cost of accidents with the notification $\left(C_{n}\right)$, where $\left(\left(C_{u n}\right)-\left(C_{n}\right)\right)>0$.

or See note 146 and accompanying text.

68 Ultimately $P^{*} L=n\left(\left(C_{w n} a\right)-\left(C_{n}\right)+\left(C_{w n} b\right)\right)$, where $n$ is the number of patients treated by the HN-positive physician, $C_{w n} a$ is the expected loss incurred by the patient without lookback, $C_{n}$ is the expected loss incurred by the patient with the lookback, and $C_{u n} b$ is the expected loss incurred by third parties exposed to HIV through interaction with the patient. 


\section{A. Cost of the Lookback}

The cost of a lookback $(B)$ must be determined on a case-bycase basis. Nevertheless, courts can often identify the types of costs they must examine and their magnitudes. ${ }^{6 \theta}$ Courts should start by considering the economic cost of actually searching the physician's records, and locating and notifying patients. The courts should also consider the privacy costs to the physician and physician's family. ${ }^{70}$ Depending on how the lookback is done and the extent to which it reflects discrimination against the physician on the basis of disability, $B$ may also include costs of discrimination. As noted above, courts' assessments of disclosure costs are, and should be, guided by such legislation as the FRA ${ }^{71}$ and the ADA. ${ }^{72}$ Other guideposts include the damages courts award as compensation for emotional distress and loss of consortium arising from disclosure. This section sets parameters and offers guidance in determining the cost of lookback $(B)$.

1. Significance of the right to privacy.

The Supreme Court has recognized that "the Constitution embodies a promise that a certain private sphere of individual liberty will be kept largely beyond the reach of government." ${ }^{33}$ One funda-mental element of the right to privacy is the ability to "avoid[] disclosure of personal matters." "74 The protection from government disclosure of personal information has been extended to a broad range of intimate information. ${ }^{75}$ Information concerning a person's

69 Existing caselaw does not yet make clear which costs are judicially recognized in the HIV status disclosure context. See, for example, Leckelt, 909 F2d at 820; Behringer, 592 A2d at 1251. The costs outlined in the text are the best approximations to date of the costs courts should consider.

${ }^{70}$ It is clear that courts recognize a privacy interest in information pertaining to HIV status. See Doe v Borough of Barrington, 729 F Supp 376, 382 (D NJ 1990) (police officer violated family members' privacy rights by disclosing citizen's HIV infection); Woods $v$ White, 689 F Supp 874, 876 (W D Wis 1988), aff'd, 899 F2d 17 (7th Cir 1990) (right of privacy covers inmates' HIV status).

7129 USC \$ 794.

7242 USC $\$ \$ 12101$ et seq.

${ }^{73}$ Thornburgh $v$ American College of Obstetricians \& Gynecologists, 476 US 747, 772 (1986) (state's law subordinating women's privacy right to abortion held unconstitutional).

74 Whalen $v$ Roe, 429 US 589, 599 (1977) (upholding, against a privacy claim, a statute requiring that official drug prescription forms identifying a patient's name be filed with the state health department).

7o See, for example, Nixon v Administrator of General Services, 433 US 425, 457 (1977) (though holding that the seizure of presidential materials for screening by government archivists did not invade a former President's privacy rights, the court rigorously scrutinized the safeguards designed to prevent disclosure of personal information); Detroit Edison Co. $v$ 
health is of particular private and personal concern..$^{76}$ In fact, "[p]robably the largest category of cases in which a right of confidentiality has been recognized includes challenges to governmental demands for medical or psychiatric information about a person." Courts have determined that information pertaining to HIV status is "of the most personal kind."

Therefore, when lookbacks are performed by government-run hospitals, ${ }^{79}$ the lookback might indeed violate constitutional privacy rights. ${ }^{80}$ Courts that recognize such a violation should consider it as a heavy cost in the $B<P^{*} L$ inequality, so costly as to be almost invariably prohibited. Similarly, lookbacks that violate privacy guaranteed by states may be so costly as to be prohibited. ${ }^{81}$

Yet, lookback need not raise a constitutional claim to create privacy costs. The constitutional right to privacy, as expressed by the Supreme Court, reflects social norms and interests. These social norms dictate consideration of intrusions on a person's privacy as a component of $B$, even when such intrusions are not unconsti-

NLRB, 440 US 301, 317-20 (1979) (upholding right to privacy for psychological testing results); Ramie v City of Hedwig Village, 765 F2d 490, 492 (5th Cir 1985) ("The disclosure strand of the privacy interest ... includes the right to be free from the government disclosing private facts about its citizens and from the government inquiring into matters in which it does not have a legitimate and proper concern.").

${ }^{76}$ See United States v Westinghouse Electric Corp., 638 F2d 570, 577 (3d Cir 1980) (allowing limited discovery of employees' medical records where interests in discovery outweigh ordinary privacy protection afforded medical records); Carter $v$ Broadlawns Medical Center, 667 F Supp 1269, 1282 (S D Iowa 1987), modified on other grounds, 857 F2d 448 (8th Cir 1988) (right to privacy extends to patient records held by a county hospital), cert denied, 489 US 1096 (1989); Shoemaker v Handel, 608 F Supp 1151, 1159 (D NJ 1985), aff'd, 795 F2d 1136 (3d Cir 1986) (right to privacy extends to avoiding disclosure of "personal medical information," but must be weighed against competing state interest).

77 Bedford v Sugarman, 112 Wash 2d 500, 509, 772 P2d 486, 491 (1989).

78 Woods, 689 F Supp at 876. See also Doe v Borough of Barrington, 729 F Supp at 382 (disclosure of information about one's exposure to or infection with the AIDS virus is disclosure of a "personal matter" within the meaning of Whalen); Behringer, 592 A2d at 127174. Courts have also determined that disclosure of the HIV status of blood donors violates Whalen. See Doe $v$ University of Cincinnati, 42 Ohio App 3d 227, 231-32, 538 NE2d 419, 423-24 (1988).

70 The Constitution, in general, controls government action, not private action.

so Depending on where the physician practices or lives, both state and federal privacy guarantees may be implicated. The privacy arguments under state constitutions generally parallel those made under the United States Constitution. For a general discussion of the privacy rights of HIV-positive health care workers, see Karen $\mathrm{H}$. Rothenberg, et al, The AIDS Project: Creating a Public Health Policy-Rights and Obligations of Health Care Workers, 48 Md L Rev 93, 106-44 (1989).

81 States may provide broader protections for privacy rights than do federal statutes or the Constitution. The Bill of Rights creates a "zone" of privacy, which states may broaden but not restrict. See Griswold v Connecticut, 381 US 479, 482 (1965). 
tutional. In the negligence equation, $B$ measures all costs, even if those costs are not constitutionally cognizable.

For example, a lookback might implicate privacy rights even if it was not conducted or authorized by a government actor. The constitutional claim, whether or not directly applicable, provides a metric against which courts can determine the costs of privacy violations. In those situations in which a lookback names an individual physician, courts should consider costs associated with invasion of that physician's privacy rights as a major component of $B$. Where the physician is not explicitly named, her privacy interest may still be implicated if there is a substantial likelihood that disclosure of practice specialty, dates of practice, and location of practice would lead to the identification of the physician.

Theoretically, friends, associates, and sexual partners of HIVinfected individuals may also suffer a loss of privacy if the identity of the infected individual is disclosed. One court has held that stigma "attaches not only to the AIDS victim, but to those in contact with AIDS patients," including family members. ${ }^{82}$ That court held that a family member's AIDS status is personal. ${ }^{83}$ Courts should vary their assessment of $B$ depending on the differing privacy costs attributable to the lookback. Those costs should include losses of privacy both to the physician and to others who suffer privacy losses as a result of the lookback.

\section{Costs of discrimination on the basis of disability.}

In ruling on disclosure of the identities of HIV-infected health care workers, the Leckelt and Behringer courts looked to federal anti-discrimination legislation for guidance. Such legislation reveals Congress's determination that discrimination on the basis of an individual's disability gives rise to compensable damages. As with the constitutional right to privacy, when lookbacks actually violate an anti-discrimination statute, $B$ may be so large as to prohibit performance of the lookback altogether. Yet, a lookback need not actually violate federal anti-discrimination law in order for it to inflict substantial costs. Both the Federal Rehabilitation Act and the Americans with Disabilities Act establish a congressional measure of the costs of discrimination for lookback.

a) The Federal Rehabilitation Act of 1973. The FRA guarantees that federally funded programs and activities will not

\footnotetext{
${ }^{82}$ Doe v Borough of Barrington, $729 \mathrm{~F}$ Supp at 384.

${ }^{83}$ Id at 386.
} 
discriminate based on disability. ${ }^{84}$ The Department of Justice and several courts have recognized all stages of HIV infection as a disability under the FRA. ${ }^{85}$ Thus, where lookback provokes discrimination against an HIV-positive employee on the basis of disability, the FRA may provide remedies to compensate discrimination costs. The costs of these remedies must be factored into the $B$ variable in the negligence equation. ${ }^{86}$ The FRA also forbids disability discrimination in programs administered by an institution that receives federal funds, even if the particular discriminatory program does not receive federal funds directly. ${ }^{87}$ Notably, most hospitals receive Medicare or Medicaid funds from the federal government and accordingly are covered by the FRA. ${ }^{88}$ Thus, any hospital, health care institution, or state department of public health that discloses its employees' HIV status may be violating the FRA, subject to the qualifications discussed below.

The Supreme Court has stated that, under the FRA, differential treatment is impermissible unless a person's handicap poses a

s4 The FRA provides, in relevant part:

No otherwise qualified individual with handicaps ... shall, solely by reason of her or his handicap, be excluded from the participation in, be denied the benefits of, or be subjected to discrimination under any program or activity receiving Federal financial assistance or under any program or activity conducted by any Executive agency or by the United States Postal Service.

29 USC \$ 794(a) (Supp 1990).

${ }^{83}$ The FRA protects from discrimination "any person who (i) has a physical or mental impairment which substantially limits one or more of such person's major life activities, (ii) has a record of such an impairment, or (iii) is regarded as having such an impairment." 29 USC $\S 706(8)$ (B) (Supp 1990). The FRA covers persons with AIDS. See Chalk $v$ US Dist. Court Cent. Dist. of California, 832 F2d 1158, 1158 (9th Cir 1987). At least one court has concluded that the FRA protects asymptomatic HIV carriers. See Doe v Dolton Elementary School District, 694 F Supp 440, 444-45 (N D III 1988). The Department of Justice has stated that all HIV-infected persons are covered by the Act. See Department of Justice Memorandum on the Application of Section 504 of the 1973 Rehabilitation Act to HIVInfected Persons, 8 Lab Rel Rptr (BNA) § 405:1 (Sep 27, 1988).

Bs FRA remedies include a private right of action, recovery of attorney's fees, and sometimes compensatory and punitive damages. See Pushkin v Regents of Univ. of Colorado, 658 F2d 1372, 1376-80 (10th Cir 1981).

87 The law provides, that for purposes of determining programs or activities "receiving financial assistance" under § 794(a), the term "program or activity" means

all of the operations of - ... an entire corporation ... or an entire sole proprietorship-

(i) if assistance is extended to such corporation ... or sole proprietorship as a whole; or

(ii) which is principally engaged in the business of providing . . . health care ...

any part of which is extended Federal financial assistance.

29 USC § 794(b)(3)(A) (Supp 1990) (emphasis added).

${ }^{88}$ See United States v Baylor University Medical Ctr., 736 F2d 1039, 1040-41 (5th Cir 1984). 
significant risk to the health and safety of others. ${ }^{89}$ In determining whether such a risk exists, courts "normally should defer to the reasonable medical judgments of public health officials." "90 Further, the Supreme Court has stated that employers making job-related decisions relying upon the infected status of an employee should do so based on the risk of exposure inherent in a specific context. ${ }^{91}$ For lookback, the broader the disclosure, the less likely that the lookback reflects a permissible differential treatment based on "significant risk." "92

Litigation involving lookbacks provides additional guidance for determining when the FRA provides a remedy for HIV status discrimination. Importantly, no precedent establishes that lookbacks are not covered by the FRA. In Leckelt, the Fifth Circuit dismissed Leckelt's FRA claim, but did so on grounds distinguishable from most lookback cases. The court found that Leckelt was terminated from employment due to his failure to comply with hospital policy and not solely because of the perception that he was HIV-positive. ${ }^{93}$ Leckelt is different from the typical lookback case because the plaintiff prevented disclosure by never turning over the HIV antibody test results. As a result, Leckelt's FRA inquiry and the court only addressed the challenged termination and not the hospital's request for his HIV test results.

Unlike Leckelt, Behringer represents a prototypical lookback FRA inquiry. However, the case was filed in state court, and the plaintiff's claims were based on state anti-discrimination legislation. The court never addressed the termination of the physician's privileges at the Medical Center under federal anti-discrimination

S9 School Board of Nassau County $v$ Arline, 480 US 273, 287 n 16 (1987) (holding that where a contagious person is also physically impaired, the court must conduct an individualized inquiry with deference to reasonable medical judgments to determine if the contagious person is "otherwise qualified" and therefore covered by the FRA).

$20 \mathrm{Id}$ at 288.

o1 According to the Arline Court, risks are assessed according to "[findings of] facts, based on reasonable medical judgments given the state of medical knowledge, about (a) the nature of the risk (how the disease is transmitted), (b) the duration of the risk (how long is the carrier infectious), (c) the severity of the risk (what is the potential harm to third parties) and (d) the probabilities the disease will be transmitted and will cause varying degrees of harm." Id at 288. This statement suggests that a case-by-case risk assessment is required.

${ }_{92}$ See Doe v Federal Bureau of Prisons, No 91-C-5013 (N D IIl, Aug 9, 1991), discussed in 1991 AIDS Litigation Rep at 6833 (cited in note 48), which involved a broad lookback that overlooked the significance of the safety risk. In Doe, the Bureau of Prisons sent letters to 2,900 former patients of an HIV-infected doctor, without regard to the patient's risk of HIV exposure, and issued a public press statement identifying the physician's medical specialty.

${ }^{83}$ Leckelt, 909 F2d at 826. 
provisions. As a result, no precedent directly establishes whether lookback violates the FRA..$^{94}$ At a minimum, then, an FRA claim is still an available avenue for redress for a person whose HIV status is revealed through a lookback.

b) Americans with Disabilities Act of 1990. The ADA expands federal protection against disability discrimination, ${ }^{85}$ including discrimination based on HIV infection or on AIDS. ${ }^{96} \mathrm{Un}$ like the Federal Rehabilitation Act, the ADA applies to discriminating parties regardless of whether they receive federal funds or qualify as federal agencies. Therefore, lookbacks that do not violate the FRA may still violate the ADA. ${ }^{97}$ As the previous section explains, an organization that does not generally reveal medical information about workers, but does so based on the worker's disability, may be subjecting its employee to discrimination on the basis of disability.

Lookbacks probably constitute judicially-recognizable disability discrimination under the ADA. Both the FRA and the ADA include HIV infection and AIDS as disabilities. ${ }^{93}$ EEOC regulations emphasize that HIV infection in all its stages is "inherently

24 In Doe $v$ Bureau of Prisons, the plaintiff made an FRA claim which the court never addressed. See 1991 AIDS Litigation Rep at 6833 (cited in note 48).

ss 42 USC $\S 12101$ et seq. The Act prohibits disability-based discrimination in employment (Title I), in the provision of public services (Title II), and by public accommodations and services operated by private entities (Title III). The ADA's employment provisions become effective July 26,1992 . The provisions for public services and public accommodations became effective January 26, 1992. The Equal Employment Opportunity Commission ("EEOC") is responsible for administering Title I of the Act and has promulgated regulations to implement the law. See 29 CFR $\S \S 1630$ et seq (1991). The Department of Justice, responsible for administering Titles II and III, has also issued implementing regulations. See 28 CFR $\S \S 35$ et seq (1991) (Title II); 28 CFR $\$ \S 36$ et seq (1991) (Title III).

98 See note 101 and accompanying text.

97 In particular, the ADA is relevant where disclosure is made by an employer not covered by the FRA, or sometimes by a party other than the health care worker's employer. Therefore, the ADA's protections against disclosure of the HIV status of infected health care workers are wider in scope than the protections afforded by the FRA. For example, the ADA makes it unlawful to "coerce, intimidate, threaten, or interfere" with any individual because the individual has exercised her rights under the ADA or helped others exercise ADA rights. 42 USC $\$ 12203(\mathrm{~b})$. This provision may require that costs incurred by the individual physician as a result of a co-worker's disclosure of the employee's HIV status be included in the calculus.

28 The intent to include HIV infection and AIDS is clearer under the ADA than under the FRA. Whereas FRA caselaw developed to include HIV infection and AIDS-see note 85 and accompanying text-the federal regulations issued to interpret the ADA expressly include all stages of HIV disease. 
substantially limiting."98 Both FRA case law ${ }^{100}$ and congressional intent $^{101}$ point to inclusion of HIV infection under the ADA as a disability in every instance.

Additionally, relatives and associates of the disabled person may raise a claim under the $\mathrm{ADA} ; ;^{102}$ the disclosure of private medical information may damage an HIV-negative person's family members. ${ }^{103}$ Thus, the ADA reflects Congress's understanding that discrimination suffered by family members-like the invasion of those persons' privacy ${ }^{104}$-must be included in evaluating total costs of disclosure.

The ADA prohibits discriminatory action taken "because of" the disability of a qualified employee. This standard is a significantly lower barrier to recovery than that of the FRA. The FRA states that discriminatory action cannot be taken "solely by reason of" an individual's disability. Hence, under the FRA, a plaintiff fails to state a claim when the discriminatory action arose from mixed motives. ${ }^{105}$ In contrast, under the ADA, plaintiffs arguably can recover even where the motives underlying the disparate treatment are not purely discriminatory.

The Leckelt court held that under the FRA, a hospital's policy requesting that a nurse reveal his HIV status was justified because the nurse posed a significant risk to patients. ${ }^{106}$ The court balanced the likelihood of transmission against the likelihood and magnitude of potential harm. Finding that the latter was significant, the court determined that the hospital's policy did not violate the FRA. Under the ADA, however, such balancing may not be permis-

${ }^{99}$ See EEOC Interpretive Guidance, 56 Fed Reg 35694 at 35741 (Jul 26, 1991) (adding $29 \mathrm{CFR} \S 1630$ ).

100 FRA case law provides a minimum standard of protection for the ADA. 42 USC $\S$ 12201(a). See also Gregory Crespi, Efficiency Rejected: Evaluating "Undue Hardship" Claims under the Americans with Disabilities Act, 26 Tulsa L J 1, 11-13 (1990).

101 See, for example, Americans with Disabilities Act of 1990, HR Rep No 485, 101st Cong, 2d Sess 52 (1990) ("a person infected with Human Immunodeficiency Virus is covered" because it substantially limits procreative and intimate sexual relationships); Americans with Disabilities Act of 1990, $S$ Rep No 116, 101st Cong, 1st Sess 20 (1989) (ADA covers HIV infection).

${ }^{102}$ See 29 CFR $\S 1630.8$ (cited in note 99), (preventing discrimination against a "qualified individual because of the known disability of an individual with whom the qualified individual is known to have a family, business, social, or other relationship or association").

${ }^{103}$ See Doe v Borough of Barrington, 729 F Supp at 386.

104 See text accompanying notes 73-83.

${ }^{105}$ See, for example, Severino v North Fort Myers Fire Control Dist., 935 F2d 1179, 1182-83 (11th Cir 1991); Norcross $v$ Sneed, 573 F Supp 533, 543 (W D Ark 1983), aff'd, 755 F2d 113 (8th Cir 1985); Pierce v Engle, 726 F Supp 1231, 1234 (D Kan 1989).

${ }^{106}$ Leckelt, 909 F2d at 833. 
sible. This suggests that Congress intended ADA violations to be more costly than FRA violations. ${ }^{107}$

Apart from the question of a statutory violation, the more fundamental point remains. Federal and state legislatures have determined that discrimination on the basis of disability creates costs. Aside from the question of whether a lookback is a statutory violation, it may create costs that must be included in the evaluation of the total costs of the lookback.

\section{Costs recoverable in tort.}

The following sections discuss whether damages due to disclosure are compensable under tort law. Where an individual raises a tort claim, the lookback may create costs even if those costs are not compensable in law. While the previous section focussed on costs imposed on the HIV-infected employee, the individuals notified incur costs as well. This discussion provides a framework for determining when courts should award damages to these individuals for emotional distress and loss of consortium. Whether or not injuries sustained as a result of lookback are recoverable in tort, the costs of emotional distress and loss of consortium must be included in the costs of lookback, even for persons who never actually contract HIV or AIDS. As with privacy rights and anti-discrimination legislation, a legal remedy is not a prerequisite to an economic analysis that accounts for disclosure costs. Rather, an evaluation of potential remedies helps provide courts with an indicia of costs associated with disclosure.

a) Emotional distress. Disclosing a physician's HIV status may inflict emotional distress upon those patients who learn they might be HIV-positive. These emotional costs of the disclosure must be included in the valuation of a lookback's burden. However, if the number of people notified that they may have been exposed relative to the number who actually do turn out to be HIV-positive is large, the overall cost of emotional distress might, on that basis alone, outweigh the benefits from the lookback.

Damages for emotional distress are a common judicial remedy. Some courts award damages for emotional and mental distress

${ }^{207}$ The claim that the balancing found in Leckelt would not be permissible under the $\mathrm{ADA}$ can also be made by relying on an interpretation of the "direct threat" defense presented in Timothy Bishop, Discrimination Against Persons with HIV Disease: The Americans with Disabilities Act, in Paul Albert, ed, National Lawyers Guild AIDS Practice Manual (National Lawyers Guild, forthcoming) (on file with U Chi L Rev). 
even absent an accompanying physical injury or illness. ${ }^{108}$ This departure makes it easier for patients-including those who never test positive for HIV-to be awarded damages for emotional distress resulting from treatment by an HIV-positive physician. If a physical injury rule is not required, then all patients of HIV-positive health care workers notified in a lookback may have a cause of action for negligent infliction of emotional distress by proving duty, breach, causation, and damages. ${ }^{109}$ Further, emotional distress may lead to anxiety disorders, a physical manifestation that makes negligence easier to prove. ${ }^{110}$ Two recent suits sought-albeit unsuccessfully-emotional distress damages that stem from mere knowledge of a former physician's death from AIDS.111 A court conducting a negligence inquiry with regard to the disclosure should consider the emotional distress of those notified as part of the cost of the lookback.

b) Loss of consortium. Patients and spouses of patients treated by HIV-infected health care workers may make claims for loss of consortium. Loss of consortium is a derivative claim that arises from a primary negligence action; the defendant's duty of reasonable care to the impaired spouse transfers to the spouse deprived of consortium. The claim includes interference with the marriage contract as evidenced by loss of support, affection, society, companionship, and loss of sexual intercourse. ${ }^{12}$ A plaintiff could claim that the potential of testing positive for HIV in the future prohibited her from having safe, unprotected sexual intercourse indefinitely. ${ }^{113}$ Limitations in the technology to test for HIV

108 See, for example, Corgan $v$ Conrad Muehling, 143 Ill 2d 296, 574 NE2d 602, 607-09 (1991) (though physical symptoms establish objective evidence of harm, absence of physical symptoms is not a justifiable reason to preclude recovery for emotional distress).

${ }^{109}$ See id at 606, citing Kirk v Michael Reese Hospital \& Medical Center, 117 Ill $2 \mathrm{~d}$ 507,525 (1987).

110 Id at 608-09.

11 Rossi v Almaraz, No 90344028 (Md Cir Ct for Baltimore City, May 23, 1991), and Faya v Almaraz, No 90345011 (Md Cir Ct for Baltimore City, May 23, 1991), were filed by former patients against a surgeon's estate after Johns Hopkins University Hospital conducted a broad lookback following the surgeon's death. The court did not address the appropriateness of the lookback, but confined its analysis to damages. Both cases were dismissed on summary judgment motions. However, these dismissals were not based on Maryland's rule preventing recovery for emotional distress absent physical injury. Rather, the court relied on a special rule: in cases involving the fear of contracting disease, plaintiffs must prove exposure.

112 Fowler V. Harper, Fleming James, Jr., and Oscar S. Gray, The Law of Torts $\$ 8.9$ at 550 (Little, Brown, $2 \mathrm{~d}$ ed 1986).

113 This claim was advanced but rejected in Rossi, No 90344028, slip op at 1 (cited in note 111). 
leave open the possibility of never-ending uncertainty as to infection status. ${ }^{114}$ Damages for loss of consortium may increase the cost of a lookback even where notified patients never test positive for HIV. Moreover, all claims raised in tort, whether or not judicially remediable, can create costs relevant to the valuation of the costs of a lookback.

\section{Systemic costs.}

Systemic costs, though difficult to evaluate, probably comprise the most significant portion of lookback costs. This section surveys and highlights costs that may result and will be borne by the society generally. These societal costs include costs to persons who are not directly affected by the lookback, that is, any persons who do not receive notification that they have been treated by an HIVinfected physician.

The first potential cost is an irrational distrust of the medical system that could lead to inefficient uses of health care resources. Though it may be difficult to figure out precisely what the burden is on society as a result of this cost, it may be significant. One could imagine that individuals might forgo medical treatments, which are otherwise recommended, because of a fear of contracting HIV. ${ }^{115}$ Alternatively, patients may make decisions to avoid being treated by doctors who they perceive pose a risk of infection; often these decisions may not have any rational basis. ${ }^{116}$ Doctors too, may make decisions not to treat patients based either on irrational fears of contracting the virus or as a response to economic pressure from their clientele. ${ }^{117}$ The existence of lookback sends an implicit

114 See note 2.

115 One dentist noted a decline in patients who seek dental care, a decline presumably attributable to a fear of contracting AIDS. See Jeffrey M. Gold, Letter to the Editor, Fear of AIDS Keeps Dentist Chairs Empty, NY Times, D14 (Nov 3, 1991). See also Mireya Navarro, Patients Grilling Health Workers on AIDS, NY Times B1 (Aug 2, 1991) (Some doctors and dentists believe that patients delay procedures and treatment because of fear of HIV infection. Dentists in the New York metropolitan area reported cancellations after the newspapers reported about the death of an HIV-infected dentist.).

${ }_{116}$ Some patients rely on personal information about health care workers to judge the risk level of contracting HIV from the health care worker. Some doctors report being asked whether they are married. One presumes that patients who ask this question seek to avoid treatment from gay doctors. See Navarro, NY Times B1. Consider too the recent spate of "1-800-DENTIST" commercials on television, in which the information provider discusses a dentist's marital status with callers. These commercials play on stereotypes and irrational fears about gay men and AIDS.

${ }^{117}$ See Jon Van, Scarlet Letters for Doctors: AIDS, Chi Trib C13 (Jun 8, 1989) (contrary to the opinion of public health authorities, $25 \%$ of persons polled would change doctors if they learned their current doctor was treating AIDS patients). 
message to health care consumers that the medical establishments themselves perceive a substantial risk of HIV transmission as a result of health care.

Another potential societal cost of lookback would be the creation of a disincentive for medical workers to notify hospitals of their HIV infection status. Furthermore, as a result of lookback policies, physicians would be discouraged from voluntarily testing. ${ }^{118}$ Particularly where lookbacks result in economic losses to the physician, either as a loss of income, ${ }^{119}$ or as a loss because of unemployment or altered employment, the physician would avoid any possibility of finding out her HIV status.

Finally, lookbacks could result in widespread disregard for safer sexual practices resulting in further spread of the virus. ${ }^{120}$ Currently, educational efforts are a primary means of preventing HIV. However, even the broadest, most intrusive lookbacks cannot ensure $100 \%$ notification of persons facing increased risk from exposure in a health care setting. ${ }^{121}$ For example, a patient who is treated at a hospital that routinely performs lookbacks may correctly assume that she will be notified if the hospital discovers that the treating physician is HIV-positive. As a result, she will not alter her behavior if she does not hear otherwise from the hospital. However, her behavior may reflect under-prevention, according to the patient's own evaluation of the appropriate prevention level, ${ }^{122}$ either because the hospital does not know the accurate HIV status of the physician or the limits of the testing technology prevent an accurate determination of the physician's HIV status. Any dimin-

118 See, for example, Tomas J. Philipson and Richard A. Posner, Optimal Regulation of $A I D S$, (unpublished manuscript, Dec 16, 1991) (on file with U Chi L Rev) (arguing that penalties such as loss of jobs, life and medical insurance, operate as a tax on voluntary testing).

110 This type of loss was experienced by the physician in Behringer.

${ }^{120}$ Professor Philipson and Judge Posner divide the world into egoists and altruists. An altruist is a person who, if she knows she is HIV-positive will engage in only safer sex, in order to protect her partner. The egoist, on the other hand, cares not at all for the safety of her partner. The HIV-positive egoist will always choose to engage in unsafe sex. The HIVnegative egoist will engage in safer sex if she believes she is at risk from her partner; and she generally cannot trust that her partner will notify her as to risk factor. Philipson and Posner conclude that anything that increases the number of egoists who are tested for the AIDS virus is questionable from a social standpoint. See Philipson and Posner, Optimal Regulation of AIDS (cited in note 118). One could extend this analysis to the lookback case. Lookbacks will not affect the altruist's behavior, which is already protective of her partner. However, lookbacks will increase the number of egoists who get tested and could therefore exacerbate the spread of HIV.

${ }^{121}$ See note 2 and accompanying text.

122 This argument assumes that a person would want to increase use of HIV prevention methods if at a higher risk of infection, in order to protect her partner. 
ished emphasis on safer sexual practices that results from reliance on lookbacks will create costs to society.

As the blood transfusion cases illustrate, courts consider the systemic costs of and society's interests in disclosure. In fact, the Rasmussen court viewed "society's interest in a strong and healthy blood supply" as the dispositive issue in the case. ${ }^{123}$ Similarly, courts should find that the societal effects and costs of disclosing the identities of HIV-infected health care workers are relevant to cost-benefit analysis.

B. Losses Prevented by Lookback Multiplied by the Probability of Harm $\left(P^{*} L\right)$

An economic analysis of lookback would compare total costs with the value of the losses prevented by disclosure. This section evaluates the probability of a loss where no lookback has been conducted, and the magnitude of that loss should it occur.

For patients who have actually contracted HIV through exposure to an HIV-positive health care worker, lookbacks and notification may provide opportunities for early medical intervention, which can extend the lifespan of the patient. Lookbacks may also prevent subsequent transmissions to third parties by patients infected by an HIV-positive health care worker. ${ }^{124}$ The maximum loss associated with such a transmission would be the death of the individual to whom the infected patient transmitted the disease. A factor as weighty as otherwise preventable death significantly affects the balance. In evaluating the total costs that society would suffer if a lookback is not conducted $\left(P^{*} L\right)$, however, courts must look not only at the loss $(L)$, but also at the probability $(P)$ that the loss will occur. If the $P$ multiplier is low, $B$ might outweigh $P^{*} L$ even if $L$ is high.

1. Risk to persons associated with a former patient of an HIV-infected health care worker.

In most cases, lookbacks help primarily those who are not HIV-positive at the time of the lookback but who are in danger of being exposed to the HIV virus. The best example of lookback beneficiaries are the sexual partners of patients exposed to the

${ }^{123}$ Rasmussen, $500 \mathrm{~S} 2 \mathrm{~d}$ at 538.

${ }^{124}$ See Gostin, $48 \mathrm{Md} \mathrm{L} \mathrm{Rev} \mathrm{at} 21$ (cited in note 57) (comparing risk of transmission from health care professional to patient with risk of transmission from patient to health care professional). 
HIV-positive health care worker. In order to evaluate the risk of transmission from the patient to any third party-secondary risk probability-a discussion of the risk of transmission from health care worker to patient-primary risk probability-is necessary. The risk to third parties is equal to the primary risk probability multiplied by the secondary risk probability. ${ }^{125}$

a) Primary risk probability. Despite ten years of experience with HIV infections, the Florida dentist case remains the only known instance of transmission of HIV from physician to patient. ${ }^{126}$ Retrospective studies of the patients of HIV-infected health care workers as well as studies performed after lookbacks confirm this finding. ${ }^{127}$

The Centers for Disease Control (CDC) has issued a draft document that quantifies the risk of HIV transmission from dentist to patient. ${ }^{128}$ As a preliminary matter, health care workers who use universal precautions ${ }^{129}$ and do not perform invasive procedures ${ }^{130}$

\footnotetext{
${ }^{125}$ For a comprehensive discussion of this formula, see Mark Barnes, et al, The HIVInfected Health Care Professional: Employment Policies and Public Health, 18 L, Med and Health Care 311 (1990).

${ }^{128}$ The CDC used DNA samples to link the strains of the virus in three of the dentist's patients to the dentist's strain. Centers for Disease Control, Update: Transmission of HIV Infection During an Invasive Dental Procedure-Florida, 40 Morbidity and Mortality Wkly Rpt, No 23, 21 (June 14, 1991). Based on DNA sequencing and the absence of other risk factors for these patients, the CDC concluded that these three patients became HIV infected while receiving care from the dentist. This dentist had a history of poor sterilization practices, using his own equipment to treat himself after being diagnosed HIV positive, and not changing gloves between patients. Id at 25-26. See also Barbara Gerbert, et al, Possible Health Care Professional-to-Patient HIV Transmission, 265 J Am Med Ass'n 1845, 1847 (1991).

${ }_{127}$ Ban Mishu, et al, A Surgeon with AIDS: Lack of Evidence of Transmission to Patients, $264 \mathrm{~J} \mathrm{Am} \mathrm{Med} \mathrm{Ass'n} 467$ (1990) (after testing 616 of a surgeon's 2160 identified patients, CDC concluded that none had acquired HIV from the surgeon); Jeffrey J. Sacks, AIDS in a Surgeon, 313 New Eng J Med 1017 (1985) (none of 400 patients of Florida surgeon was listed in the Florida AIDS Registry); Frances Armstrong, Judson Miner, and William Wolfe, Investigation of a Health Care Worker with Symptomatic Human Immunodeficiency Virus Infection: An Epidemiologic Approach, 152 Military Med 414 (1987) (76 patients of HIV-infected surgeon sought testing and none tested positive for HIV); Porter, et al, Management of Patients Treated by a Surgeon with HIV Infection, I The Lancet 113 (1990) (76 of 339 patients of surgeon asked for testing; none was HIV-infected).

${ }^{228}$ Centers for Disease Control, DRAFT: Estimates of the Risk of Endemic Transmission of Hepatitis B Virus and Human Immunodeficiency Virus to Patients by the Percutaneous Route During Invasive Surgical and Dental Procedures, (Jan 30, 1991) ("DRAFT") (on file with U Chi L Rev). The courts, as a descriptive matter, pay deference to CDC estimates, in part because they are admissible under a hearsay exception for government documents. Courts should also hear expert testimony to ensure accurate estimates of transmission risks.

128 "Universal precautions" are defined in Centers for Disease Control, Recommendations for Preventing Transmission of Human Immunodeficiency Virus and Hepatitis B Vi-
} 
present no risk of HIV transmission to patients. The CDC estimates that during "dental procedures performed by a dentist or oral surgeon which predictably result in patient bleeding,"131 the risk that a patient will be infected by an HIV-positive dentist ranges from 1 in 263,158 to 1 in 2,631,579.132 The risk that a patient will be infected by an HIV-positive surgeon ranges from 1 in 41,667 to 1 in $416,667 .{ }^{133}$ Based on these figures, the CDC estimates that during the years 1981-1990 only between ten and one hundred patients were infected with HIV by dentists. ${ }^{134}$ Courts should be wary, however: the CDC noted that its ability to estimate risk in the dental-care setting was hampered by "the lack of prospective studies of the frequency of percutaneous injuries in [dental] workers and the percent of such injuries which result in possible exposure of a patient to the worker's blood."135 Additionally, many have criticized the CDC study ${ }^{136}$ and its underlying assumptions. ${ }^{137}$ Critics suggest the actual instances of transmission are much lower. No other official report attempts to quantify the

rus to Patients During Exposure-Prone Invasive Procedures, 40 Morbidity and Mortality Wkly Rpt, No RR-8, 1, 2 (Jul 12, 1991).

2s0 Invasive procedures involve "surgical entry into tissues, cavities, or organs or repair of major traumatic injuries." CDC, 36 Morbidity and Mortality Wkly Rpt Supp at 6 (cited in note 5).

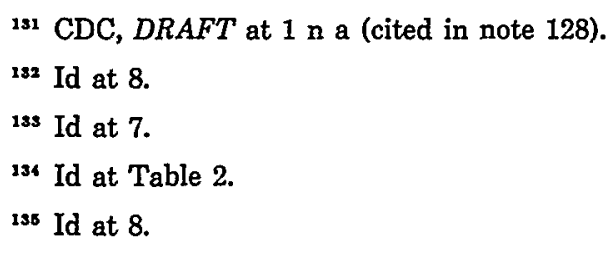

138 Dr. Henry Finger, President of the Academy of General Dentistry, criticized as too high an estimate of patient risk presented in the CDC's draft document in a March 11, 1991 letter to the CDC, which is discussed in Zev Remba, HIV, 1991 AGD Impact 16, 20 (June).

${ }^{237}$ Testifying through one of its members at the CDC Conference on Health Care Worker Guidelines (Feb 21, 1991), the AIDS Action Council ("AAC") argued that the CDC's study relies on unfounded assumptions. The AAC contended the CDC has no basis for its assumption that sharp instruments or needles that cause percutaneous injury to the dentist recontact the patient at a $32 \%$ rate. Ruth Finkelstein, AIDS Action Council Testimony Presented to the Centers for Disease Control (Feb 21, 1991) (on file with U Chi L Rev). This figure was derived by CDC observers conducting a prospective investigation of surgical procedures at four hospitals. Because of the vast range of recontact rates noted in CDC's small sample (range among medical specialties, $8 \%$ - 57\%; range among hospitals, $24 \%$ $42 \%$ ), the $32 \%$ figure is problematic even for surgery. The AAC also criticized the CDC modelling assumptions, which relied on studies spanning a ten-year period, and ignored changes in the use of universal precautions. Id at 3-5. 
primary risk probability. ${ }^{138}$ By all reports, the probability that any patient will contract HIV from an infected physician is very low.

b) Risk of transmission from HIV-infected patient to a third party. For secondary HIV transmission, the primary means of transmission are sexual contact, needle-sharing, and a fetus's contact with an HIV-infected mother. ${ }^{139}$ Although evidence suggests that the likelihood of transmission increases with frequency of exposure, ${ }^{140}$ the probability of transmission for any single instance of exposure is uncertain although some researchers have tried to quantify the risk. ${ }^{141}$

Notably, casual contact is not a mode of HIV transmission. HIV cannot be transmitted through food handling. ${ }^{142}$ Personal ser-

${ }^{138}$ Reports state that the risk to a surgeon from operating on an HIV-infected patient ranges from 1 in 4,500 to 1 in 130,000. See Michael Hagen, Klemens Meyer, and Stephen Pauker, Routine Preoperative Screening for HIV: Does the Risk to the Surgeon Outweigh the Risk to the Patient?, $259 \mathrm{~J}$ Am Medical Ass'n 1357, 1358 (1988) ("That there would be far fewer instances of health care worker to patient transmission than of transmission from patient to health care worker would be expected."). See also Barnes, et al, $18 \mathrm{~L}$, Med and Health Care at 312 (cited in note 125).

${ }^{138}$ See Centers for Disease Control, Public Health Service Guidelines for Counseling and Antibody Testing to Prevent HIV Infection and AIDS, 36 Morbidity and Mortality Wkly Rpt No 31, 509 (Aug 14, 1987).

${ }^{140}$ See Thomas A. Peterman and James W. Curran, Sexual Transmission of Human Immunodeficiency Virus, $256 \mathrm{~J}$ Am Medical Ass'n 2222 (1986).

${ }^{141}$ One study calculated the following levels of risk of contracting HIV:

One encounter with an individual whose HIV status is unknown and who is not in a high-risk group for HIV:

with condom use- 1 in 50 million

without condom use- 1 in 5 million

500 encounters with an individual whose HIV status is unknown and who is not in a

high-risk group for HIV:

with condom use -1 in 110,000

without condom use- 1 in 16,000

One encounter with an individual whose HIV status is unknown and who is in a high-

risk group for HIV:

with condom use- 1 in 100,000 to 1 in 10,000

without condom use-1 in 10,000 to 1 in 1,000

500 encounters with an individual whose HIV status is unknown and who is in a high-

risk group for HIV:

with condom use- 1 in 210 to 1 in 21

without condom use-1 in 32 to 1 in 3

One encounter with an HIV-positive individual:

with condom use- 1 in 5,000

without condom use-1 in 500

Norman Hearst and Stephen B. Hulley, Preventing the Heterosexual Spread of AIDS, 259

J Am Medical Ass'n 2428, 2429 (1988).

${ }^{142}$ The ADA requires that the Secretary of Health and Human Services ("HHS") create a list of diseases which may be transmitted through food handling. HHS's list, does not 
vice workers with HIV also provide no risk of transmission. ${ }^{143}$ Studies reveal that persons with HIV pose no risk to the family members or health care professionals who provide their daily care. ${ }^{144}$

2. Possibilities and benefits of early intervention and notification.

Lookback and notification inform patients of their possible exposure to HIV. As a result of this information, a patient who has been infected by a health care provider may seek to avoid transmission to third parties by avoiding known high-risk activities. This individual may also seek to reduce the cost of exposure to herself through medical intervention, which has been shown to increase the lifespan of HIV-infected persons. ${ }^{145}$ Similarly, any individual who has been exposed to an HIV-infected patient may also choose early medical intervention. Future research may reveal that medical intervention can significantly decrease the cost of loss associated with contracting HIV. Given existing technology, the benefits of early intervention are minimal. Courts, however, should consider current research on early interventions as relevant to the cost-benefit analysis.

\section{Balancing the Equation}

Courts should recognize that disclosure introduces costs to individuals and to society, and presents benefits that vary with the procedures performed by HIV-infected health care workers. The magnitude of the costs of a lookback will vary on a case-by-case

include HIV infection or AIDS. See Diseases Transmitted Through the Food Supply, 56 Fed Reg 40897 (Aug 16, 1991).

14 The latest CDC guidelines state that HIV-infected individuals whose jobs involve close personal contact with clients, such as hairdressers, barbers, estheticians, cosmetologists, manicurists, pedicurists and massage therapists, pose no threat in the absence of other infections or illnesses for which any personal service worker should also be restricted. See CDC, 36 Morbidity and Mortality Wkly Rpt Supp 2 at 8 (cited in note 5).

14 See Gostin, $48 \mathrm{Md} \mathrm{L} \mathrm{Rev} \mathrm{at} 33$ (cited in note 57).

145 See Gerald H. Friedland, Early Treatment for HIV: The Time Has Come, $322 \mathrm{New}$ Eng J Med 1000, 1001 (1990) (The initiation of zidovudine ("AZT") therapy in HIV-positive patients with no symptoms of AIDS significantly delayed the onset of AIDS). Note, however, that AZT therapy has accompanying side effects. No consensus exists regarding prophylactic use of AZT by HIV-negative persons who are at risk of HIV infection. See Centers for Disease Control, Public Health Service Statement on Management of Occupational Exposure to Human Immunodeficiency Virus, Including Considerations Regarding Zidovudine Postexposure Use, 39 Morbidity and Mortality Wkly Rpt No RR-1, 1, 7-8 (Jan $26,1990)$. 
basis. The cost of privacy invasion, for example, depends on the degree and type of disclosure. The benefits vary depending on the individualized risk of transmission of HIV to a patient. Variables that affect risk include the type of procedure performed, ${ }^{146}$ use of universal precautions, and known instances of accidents that may increase the risk. ${ }^{147}$

Due to the high costs of disclosing an individual's HIV infection status-including invasion of privacy, costs of discrimination, costs sounding in tort, and systemic costs-relative to the low probability of transmission, lookback notification is not appropriate in most cases: its costs generally outweigh the losses it would prevent. However, courts may appropriately allow or require lookbacks when the evidence demonstrates an increased probability of transmission. The following practices or occurrences suggest an increased probability of transmission: (1) failure to follow accepted infection control practices, (2) identified instances of blood-toblood contact through needlesticks, (3) accidental injury to a physician during an invasive procedure, and (4) the presence of lesions or open sores on a physician during a procedure. ${ }^{148}$

When the evidence suggests a high probability of transmission from the physician to identified patients, courts should require that those patients, and only those patients, be notified. Moreover, courts should require modified notifications, restricting the information included in the disclosure, except when full disclosure is absolutely necessary. ${ }^{149}$ In the blood transfusion cases, courts have

146 The CDC has left it to medical organizations and institutions to identify specific procedures as "exposure prone." CDC, 40 Morbidity and Mortality Wkly Rpt No RR-8 at 4 (cited in note 129). Note that the CDC and the professional organizations could not agree on a list of high-risk procedures. The CDC has abandoned its efforts to create such a list. See Lawrence K. Altman, U.S. Backs Off on Plan to Restrict Health Workers With AIDS Virus, NY Times AI (Dec 4, 1991).

${ }_{147}$ Accidents that increase the risk of HIV transmission include needlesticks and contact with an HIV-infected health care worker's open sores.

${ }_{148}$ Available evidence supports disclosure in the case of the Florida dentist who allegedly transmitted HIV to his patients. Accounts and records show that he failed to follow accepted infection control practices and repeatedly treated his own lesions with office instruments and did not later sterilize the equipment. See note 126 and accompanying text.

${ }^{149}$ In Doe $v$ Federal Bureau of Prisons, the plaintiff was the only dentist at the named facility for at least seven years. When the individual was identified by his profession, his name was not necessary to identify him. See 1991 Aids Litigation Rep at 6833 (cited in note 48). This case provides an example of when modified disclosure-blocking release of the plaintiff's medical specialty - could have significantly reduced the costs of the disclosure while maintaining the same level of benefit. 
achieved analogous results by crafting modified discovery orders subject to judicial oversight. ${ }^{150}$

The application of the framework developed in this Comment suggests that the outcomes of several of the lookback cases were wrong. In Leckelt, the court acknowledged that the health care worker's HIV status was private except insofar as the information was needed by hospital personnel to protect the health of employees and patients. ${ }^{151} \mathrm{Had}$ the Leckelt court relied on the model proposed by this Comment, it would first have undertaken an individualized risk assessment, and only then allowed limited disclosure to hospital personnel on an "as needed" basis with assurances for confidentiality. Absent assurances for confidentiality, the court should not have allowed the disclosure.

In Doe $v$ Bureau of Prisons, although the prison itself acknowledged that an effective response required notification of only a handful of former patients, ${ }^{152}$ the Federal Bureau of Prisons issued a press release. The scope of disclosure was particularly overbroad, especially considering that this health care worker had provided medical care only to a closely controlled, known population and not to the general population. Courts should limit disclosure to patients with an identifiable high risk of exposure.

\section{ConCLUSION}

Increasingly, courts are asked to establish the contours of public access to information regarding the HIV-infection status of health care workers. No coherent standard has yet emerged to guide the courts in making these decisions. This Comment's model and proposed economic analysis of the costs and benefits of lookback may prove useful in setting the level of due care in negligence actions. If accepted by the courts, the economic model would encourage hospitals and health care organizations to perform lookbacks only when they are economically efficient.

The standard that courts choose to apply will determine how zealously individuals' privacy rights are protected and will affect

${ }^{160}$ See Boutte, 127 FRD at 126; Belle Bonfils, 763 P2d at 1013; Mason, 121 FRD at 303.

${ }^{161}$ Leckelt, $909 \mathrm{~F} 2 \mathrm{~d}$ at 833.

${ }^{162}$ The CDC recommended notification of several patients, including one patient during whose treatment the dentist sustained a needlestick injury. In addition, the $\mathrm{CDC}$ recommended that patients treated during a one to two week period in which the dentist exhibited a skin condition be notified, counseled, and offered testing for HIV infection. Centers for Disease Control, Preliminary Summary of an Investigation of U.S. Public Health Service Dentist with HIV Infection 5 (Aug 8, 1991) (on file with U Chi L Rev). 
society's efforts to control the spread of a deadly virus. Decisions made in the courts will also affect legislatures and health care institutions. Each lookback decision should balance all costs to the individual and society against the benefits of disclosure. Courts should ultimately make the cost efficient choice based on accurate medical information. 